\title{
Effects of topical application of pure and ozonized andiroba oil on experimentally induced wounds in horses
}

\section{Efeitos do uso tópico do óleo de andiroba puro e ozonizado em feridas induzidas em cavalos}

\author{
Anderson Luiz de ARAÚJO'; Fernanda de Almeida TEIXEIRA²; Tracy Ferreira LACERDA²; \\ Mayra Cunha FLECHER ${ }^{3}$; Vinicius Ricardo Cuña de SOUZA ${ }^{4}$; Clarisse Simões $\mathrm{COELHO}^{5}$ \\ ${ }^{1}$ Universidade Federal da Bahia, Hospital Veterinário, Salvador - BA, Brazil \\ ${ }^{2}$ Universidade Vila Velha, Programa de Pós-Graduação em Ciência Animal, Vila Velha - ES, Brazil \\ ${ }^{3}$ Universidade Vila Velha, Faculdade de Veterinária, Vila Velha - ES, Brazil \\ ${ }^{4}$ Universidade Federal da Bahia, Instituto de Ciências da Saúde, Salvador - BA, Brazil \\ ${ }^{5}$ Universidade Federal da Bahia, Escola de Medicina Veterinária e Zootecnia, Departamento de Anatomia, \\ Patologia e Clínicas Veterinárias, Salvador - BA, Brazil
}

\begin{abstract}
The aim of this study was to evaluate clinical and histopathological aspects of topical application of pure and ozonized andiroba oil (Carapa guianensis Aublet.) on the healing process of wounds in healthy horses. Eight $6.25 \mathrm{~cm}^{2}$ wounds were surgically produced on each horse, from the cranial region to the sacrum, being four wounds on each side of the lumbar region. In three animals, left side was used for macroscopic observations and area measurement and right side was used for histopathological analysis. For the other two animals, evaluations were inverted. The beginning of the topical treatment occurred 12 hours after surgical induction of the injuries and was maintained daily until complete healing of the wounds, using saline solution (GC), ozonized saline solution (GO) sequentially and bilaterally in the craniocaudal direction, pure andiroba oil (GAP) and ozonized andiroba oil (GAO). Randomly, the sequence of the treatments was modified. Macroscopic and histopathological analyses were performed at 3, 7, 14, and 21 days after surgery. The time for complete healing of all wounds was recorded. A wound contraction of $67.75 \%$ for GC, $65.26 \%$ for GO, $67.91 \%$ for GAP, and $69.84 \%$ for GAO were recorded. Histopathologic evaluation revealed that wounds from the GAO and GAP had an advanced epithelialization, fibroblast proliferation and collagen deposition, moderate vascular proliferation, and presence of PMN infiltrate and discrete viewing of MN. It was possible to conclude that all treatments had benefits when comparing to control group, concluding that both pure and ozonized andiroba oil may be good options for treating wounds in horses.
\end{abstract}

Keywords: Carapa guianensis. Healing process. Equines. Wounds. Ozone.

\section{Resumo}

Este trabalho realizou uma avaliação clínica e histopatológica da aplicação tópica do óleo de andiroba (Carapa guianensis Aublet), puro e ozonizado, no processo de cicatrização de feridas em cinco equinos saudáveis. Oito feridas de $6,25 \mathrm{~cm}^{2}$ foram induzidas cirurgicamente, quatro de cada lado da região lombar, craniais em relação à região sacral. Em três animais, o lado esquerdo foi destinado à avaliação macroscópica e mensuração de área, enquanto o lado direito foi destinado à análise histopatológica. Nos outros dois animais, as avaliações foram invertidas. O tratamento tópico foi iniciado 12 horas após a indução cirúrgica e foi mantido diariamente até a completa cicatrização das feridas. Foram usados, sequencialmente e bilateralmente, no sentido craniocaudal: solução salina (GC), solução salina ozonizada (GO), óleo de andiroba puro (GAP) e óleo de andiroba ozonizado (GAO). Aleatoriamente, a sequência de tratamentos foi modificada. As análises macroscópicas e microscópicas foram realizadas 3, 7, 14 e 21 dias após a cirurgia, e o tempo total para cicatrização registrado. A contração da ferida foi de 67,75\% para GC, 65,26\% para GO, 67,91\% para GAP, e 69,84\% para GAO. A avaliação histopatológica demonstrou que as feridas tratadas com GAO e GAP apresentaram uma avançada epitelização, proliferação fibroblástica e deposição de colágeno, moderada proliferação vascular e presença de infiltrados de células polimorfonucleares (PMN) e discreta proliferação de células mononucleares (MN). Foi possível concluir que todos os tratamentos usados foram benéficos perante o grupo de controle, mostrando que as versões pura e ozonizada do óleo de andiroba representam alternativas terapêuticas ao tratamento de feridas em equinos.

Palavras-chave: Carapa guianensis. Cicatrização. Cavalos. Feridas. Ozônio. 
Correspondence to:

Clarisse Simões Coelho

Universidade Federal da Bahia

Avenida Adhemar de Barros, 500

CEP 40170-110, Salvador, BA, Brazil

E-mail: clarisse.coelho@ufba.br

Received: 03/04/2016

Approved: 12/01/2017

\section{Introduction}

Healing process is subject of clinical, scientific, and economical interest (HUSSNI et al., 2010), particularly in equine species in which skin healing tends to occur in a differentiated manner with a tendency to form an exuberant granulation tissue, thus impairing the animal's function (STASHAK, 1994).

There are many studies conducted in order to prove the effectiveness of oils and phytotherapeutics on wound healing in humans and animal species, being possible to highlight researches involving copaiba oil (CAVALCANTI NETO et al., 2005), papain (LEITE et al., 2012), sugar (LIMA et al., 2012), barbatimão (VIANA et al., 2014), passion fruit (GARROS et al., 2006), and sunflower-seed oil (MARQUES et al., 2004). Some topical preparations have already been tested in skin wounds in horses (MARTINS et al., 2003; SOUZA et al., 2006; COELHO et al., 2012, OLIVEIRA JÚNIOR et al., 2012).

Some andiroba oil properties have been proven, such as insect repellent (FREIRE et al., 2006), mite control (FARIAS et al., 2007), and combating intestinal sepsis (TEIXEIRA et al., 2012). Although, the use of andiroba oil in natura generated impairment in the healing process with delayed wound contraction and epithelialization in skin wounds in rats (BRITO et al., 2001). Other studies proved that this oil has analgesic, anti-allergic, and antihistaminic activity, inhibiting the formation of local edema (PENNAFORTE, 2003). Antiedema and analgesic properties of andiroba oil and a derived fraction of this oil, rich in tetranortriterpenoids, were confirmed in Swiss C57/BL10 strain mice with induced pleurisy and edema of the limbs (PENIDO et al., 2005) and zymozan-induced arthritis (PENIDO et al., 2006).

More recent therapeutic protocols recommend combination of vegetable oils with medical ozone for the treatment of wounds due to its oxidant properties, its bactericidal and bacteriostatic effects, and its ability to promote granulation tissue formation (KIM et al., 2009). Therapeutic effects of topical ozone application have been studied in the healing skin of guinea pigs (Cavia porcellus) (KIM et al., 2009), which demonstrated that presence of ozone accelerated skin repair. Similarly, ozonized sesame oil at a concentration of $1631 \pm 64 \mathrm{mEq} / 1000$ was able to accelerate the healing process in the initial phase (VALACCHI et al., 2010).

The aim of this study was to evaluate the clinical and histopathological aspects of topical application of pure and ozonized andiroba oil (Carapa guianensis Aublet.) in the healing process of experimentally induced wounds in the lumbar area of healthy horses.

\section{Material and Methods}

The project was approved by the Ethics Committee for Animal Use at Universidade Vila Velha (CEUA-UVV), Protocol 216/2012.

Five healthy crossbred horses were used, mean weight of $278.0 \pm 79.5 \mathrm{~kg}$ and mean age of $8.4 \pm 3.6$ years. All animals were considered normal after physical examination (without skin abnormalities present), complete blood cell count, and parasitological examination. The horses were kept stabled in an Equestrian Center (Centro Capixaba de Hipismo $\mathrm{CCH}$ ) in the city of Serra, Espirito Santo, Brazil, where they were adapted for a 2-week period before the onset of the

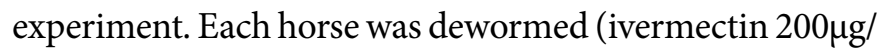
$\mathrm{kg}$ BW, orally), vaccinated against influenza, tetanus, and encephalitis (Tri-Equi-Hertap, Hertape Calier Saúde Animal Juatuba, MG, Brazil), and dentistry was performed to remove sharp points. Animals were fed hay (Cynodon dactylon) and mineral salt ad libitum, and commercial concentrate feed containing $12 \%$ protein ( $1 \%$ body weight), being kept in individual stalls during the evaluation period. Water was also provided ad libitum.

Ozonized isotonic solution (used in ozone group; GO) and ozonized andiroba oil (GAO) were produced by an ozone generator (Ozone \& Life model 0\&L 3.0 RM). The equipment contains an oxygen flow regulator, which allows flow variations from 0 to $1.0 \mathrm{~L} / \mathrm{min}$. The higher the oxygen flow, the lower the ozone concentration. Oxygen used was stored in a medical oxygen cylinder. Three hundred milliliters of isotonic sodium chloride solution $(\mathrm{NaCl} 0.9 \%)$ were placed in a graduated glass beaker $(1000 \mathrm{~mL})$, with a $0.3 \mathrm{~L} / \mathrm{ml}$ flux, concentration $25 \mathrm{mg}$ and dosing device 9 for a period of time of $2 \mathrm{~h} 30 \mathrm{~min}$ and, through bubbling, $\mathrm{NaCl}$ $0.9 \%$ solution was obtained with $1.125 \mathrm{mg}$ or mass of ozone. After preparation, solution was distributed in amber vials of $50 \mathrm{~mL}$ each, sealed and stored in a refrigerator at $4^{\circ} \mathrm{C}$. The 
same procedure was repeated to prepare ozonized andiroba oil. Both solutions, in addition to pure andiroba oil, were sent to the Laboratory of Natural Products at UVV-ES for analysis of peroxide index, saponification, and iodine index.

Hay and commercial feed were withheld from all horses for 12 hours prior to surgery, with free access to water. Animals were placed in restraining stocks and sedation was performed using $10 \%$ xylazine $(1 \mathrm{mg} / \mathrm{kg}$, intravenously). In the lumbar area, local anesthesia was achieved using 2\% lidocaine with vasoconstrictor, performing an inverted $\mathrm{L}$ block on both sides. Lumbar area was clipped and aseptically prepared using povidone-iodine 5\% solution and $70 \%$ alcohol. Four $6.25 \mathrm{~cm}^{2}(2.5 \times 2.5 \mathrm{~cm})$ wounds were surgically produced on each side of the lumbar region in each horse (cranial to the sacrum, ventral to L1-L6), with aid of a number 22 scalpel. Wounds were measured using a digital pachymeter (Starrett 727-6/150; L.S. Starrett Company, CA, USA). Excision depth included skin and subcutaneous tissue. After surgery, each horse was treated with phenylbutazone ( $4.4 \mathrm{mg} / \mathrm{kg}$, intravenously) every 24 hours for 3 days to control edema and pain (GOMEZ et al., 2004).

Topical treatment began 12 hours after surgery and was repeated daily until the complete healing of the wounds, and (1) Isotonic sodium chloride solution ( $\mathrm{NaCl} 0.9 \%)$ (GC); (2) Ozonized isotonic sodium chloride solution (GO); (3) Pure andiroba oil (GAP); (4) Ozonized andiroba oil (GAO) were used sequentially and bilaterally in craniocaudal direction for the lumbar wounds. Initially, wounds were rinsed with gauze soaked in isotonic sodium chloride solution ( $\mathrm{NaCl} 0.9 \%)$. Then, application of the treatments mentioned above was performed using gauze on the wounds. The sequence of the treatments was alternated randomly.

Macroscopic evaluation of lumbar wounds was performed on the left side of three horses. Subjective macroscopic evaluation (qualitative observation of edema presence, hyperemia, exudation, granulation tissue, and crusts), objective area measurement (using a digital pachymeter - Starrett 727-6/150; L.S. Starrett Company, CA, USA), and photographic documentation (using a Sony digital camera, model Cyber-shot DSC-H9 model, $16.2 \mathrm{mega}$, at a distance of about $30 \mathrm{~cm}$ to obtain a good focus) were performed on the day of surgery and on days $3,7,14$, and 21 postoperatively by a veterinarian blinded to the treatment.

The wound area was estimated (MAGALHÃES et al., 2008) using the following equation: $\mathrm{A}=\pi \times \mathrm{R} \times \mathrm{r}$ (where $\mathrm{A}$ represents the area, $\mathrm{R}$ represents the greatest distance and $r$ the shortest distance recorded in the wound).

The degree of contraction of the wounds was calculated by the following equation (OLIVEIRA JÚNIOR et al., 2012): Degree of contraction (\%) $=100 \times(F 0-F A) / F 0$ (where F0 is the original wound area and FA represents the area at the time of evaluation, performed at 21 days).

In these same three horses, biopsy samples for histopathological examination were obtained using a $6 \mathrm{~mm}$ skin punch (Brasmed Equipamentos Veterinários, Paulínia, SP, Brazil) on wounds on the right side on days 3, 7, 14, and 21 after surgery. For this, the same sedation protocol and local anesthesia previously described were followed, without posterior use of nonsteroidal anti-inflammatory drugs. Biopsy specimens included limits of the wounded area and undamaged tissue and were taken around the wound to ensure that none of the previous biopsy sites were included. After withdrawal, samples were placed in $10 \%$ formalin and they were sent for histological evaluation by a pathologist blinded to the type of the treatment and timing of the samples to avoid induced results (WENDT, 2005).

Specimens were fixed in $10 \%$ formalin for 12 hours and they were embedded in paraffin and sectioned at $4 \mu \mathrm{m}$ thickness with the aid of a microtome (LEICA RM 2125 RT; Leica Microsystems, Nussloch, Germany). Later they were stained with hematoxylin-eosin (HE) and subjective evaluation was performed using magnification of $100 \mathrm{x}$ and 400x (Olympus DX51, Olympus, Tokyo, Japan) focusing mainly on the presence of inflammatory infiltrate, exuberant granulation tissue, neovascularization, necrosis, and collagen fiber organization (GARROS et al., 2006; SOUZA et al., 2006).

In the remaining horses, inversion of the sides was performed (left side for microscopy and right side, macroscopy). This selection was made randomly.

During experimental period, animals were clinically evaluated twice a day. The period for the complete healing of the wounds was recorded in all treatments.

Analysis of the wound area data was performed using computer software GraphPad InStat 3.00 (GraphPad Software, CA, USA). Comparisons between treatments were made using Tukey test, considering significant when $\mathrm{p}<0.05$.

\section{Results}

Chemical analyses of pure and ozonized andiroba oils were conducted on the same day. Results showed acid values 
of $19.0 \pm 0.4$ and $18.7 \pm 0.2 / 100 \mathrm{~g}, \mathrm{mEq} / \mathrm{kg}$ in $\mathrm{KOH}$ per gram of oil, peroxide values of $3.0 \pm 0.0$ and $51.1 \pm 5.6 / 100 \mathrm{~g}, \mathrm{mEq} /$ $\mathrm{kg}$ in $\mathrm{KOH}$ per gram of oil, saponification index of $301 \pm 3$ and $269 \pm 1.0 / 100 \mathrm{~g}, \mathrm{mEq} / \mathrm{kg}$ in $\mathrm{KOH}$ per gram of oil, iodine index of $9.2 \pm 0.4$ and $5.8 \pm 0.6 / 100 \mathrm{~g}, \mathrm{mEq} / \mathrm{kg}$ in $\mathrm{KOH}$ per gram of oil, respectively for pure oil and the ozonized oil.

During the whole period of the experiment, no clinical abnormalities were observed. Table 1 shows mean values and standard deviations for the areas of the lumbar wounds throughout the trial period, where it is possible to observe the significant reduction of the wound area for all groups $(\mathrm{p}<.0001)$. Comparing the moments for the different treatments, there was a significant difference $(\mathrm{p}=.0188)$ in the area of the wounds only on the $14^{\text {th }}$ day of evaluation. Relative degree of contraction recorded in the wounds was $67.75 \%$ for GC, $65.26 \%$ for GO, 67.91\% for GAP, and $69.84 \%$ for GAO.

On the macroscopic evaluation (Figure 1), it was possible to observe that the main differences between groups were recorded between the $7^{\text {th }}$ and the $14^{\text {th }}$ day of treatment. In both GC and GAP groups, a discrete exuberant granulation tissue was observed from the $14^{\text {th }}$ day of treatment. No specific treatment for the exuberant granulation tissue was done.

Table 1 - Mean values of areas of the lumbar wounds experimentally induced in horses treated with saline $\mathrm{NaCl} 0.9 \%$ (GC), ozonized saline (GO), pure andiroba oil (GAP), and ozonized andiroba oil (GAO) - Vila Velha - 2016

\begin{tabular}{lcccccc}
\hline & Day 0 & Day 3 & Day 7 & Day 14 & Day 21 & p \\
\hline GC & $19.63 \pm 0.00^{\mathrm{a}}$ & $22.40 \pm 3.93^{\mathrm{ab}}$ & $25.11 \pm 2.06^{\mathrm{b}}$ & $12.12 \pm 0.27^{\mathrm{CAC}}$ & $6.33 \pm 1.65^{\mathrm{d}}$ & $<0.0001$ \\
GO & $19.63 \pm 0.00^{\mathrm{a}}$ & $21.21 \pm 3.17^{\mathrm{ab}}$ & $24.09 \pm 2.71^{\mathrm{b}}$ & $13.44 \pm 0.71^{\mathrm{CBC}}$ & $6.82 \pm 1.37^{\mathrm{d}}$ & $<0.0001$ \\
GAP & $19.63 \pm 0.00^{\mathrm{a}}$ & $20.60 \pm 3.55^{\mathrm{ab}}$ & $22.49 \pm 2.69^{\mathrm{b}}$ & $12.49 \pm 1.91^{\mathrm{CAC}}$ & $6.30 \pm 0.96^{\mathrm{d}}$ & $<0.0001$ \\
GAO & $19.63 \pm 0.00^{\mathrm{a}}$ & $25.05 \pm 4.71^{\mathrm{ab}}$ & $20.82 \pm 2.19^{\mathrm{b}}$ & $10.14 \pm 2.11^{\mathrm{cdA}}$ & $5.92 \pm 2.24^{\mathrm{d}}$ & $<0.0001$ \\
\hline
\end{tabular}

Note: Different lowercase letters in the same line are significantly different between $(\mathrm{p}<.05)$. Different upper letters in the same column are significantly different $(\mathrm{p}<.05)$

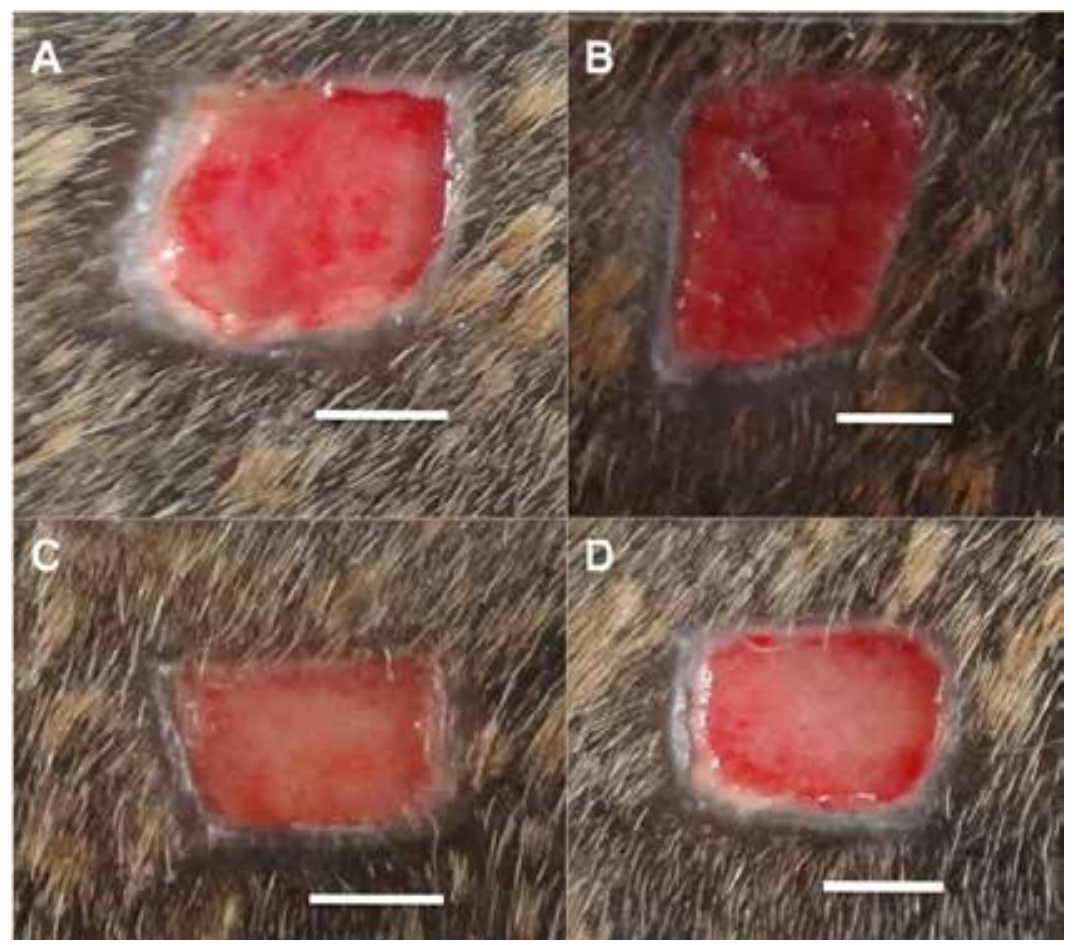

Figure 1 - Macroscopic views of lumbar wounds experimentally induced in one of the horses showing the wounds of the control group (GC) (A); those treated with ozonized saline (GO) (B); those treated with pure andiroba oil (GAP) (C); and those treated with ozonized andiroba oil (GAO) (D), on the $14^{\text {th }}$ day of evaluation. It is possible to observe a well-defined transition area with no formation of exuberant granulation tissue in GAO (D). Bar: $1 \mathrm{~cm}$ 
From the $3^{\text {rd }}$ day of treatment, absence of local pain in wounds treated with andiroba (GAO and GAP) was detected, that is, animals showed no signs of discomfort such as skin tremors, response to manipulation, or even moans during manipulation of these wounds. In contrast, produced pain was observed in the wounds of GC and GO groups.

Healing times for the studied wounds were similar, occurring at 30 days for GAO and GAP, 32 days for GO, and 31 days for GC.
On day 3, histopathological evaluation (Figure 2), all groups were similar, with no collagen deposition and discrete fibroblast proliferation. Moderate vascular proliferation, severe presence of polymorphonuclear cells (PMN), and discrete visualization of mononuclear (MN) was observed. Significant differences were noted from the $7^{\text {th }}$ day of treatment, when fibroblast proliferation and discrete vascular proliferation with presence of PMN and $\mathrm{MN}$ infiltration were observed in the wounds of the groups GAO, GA, and GO when compared to the GC.

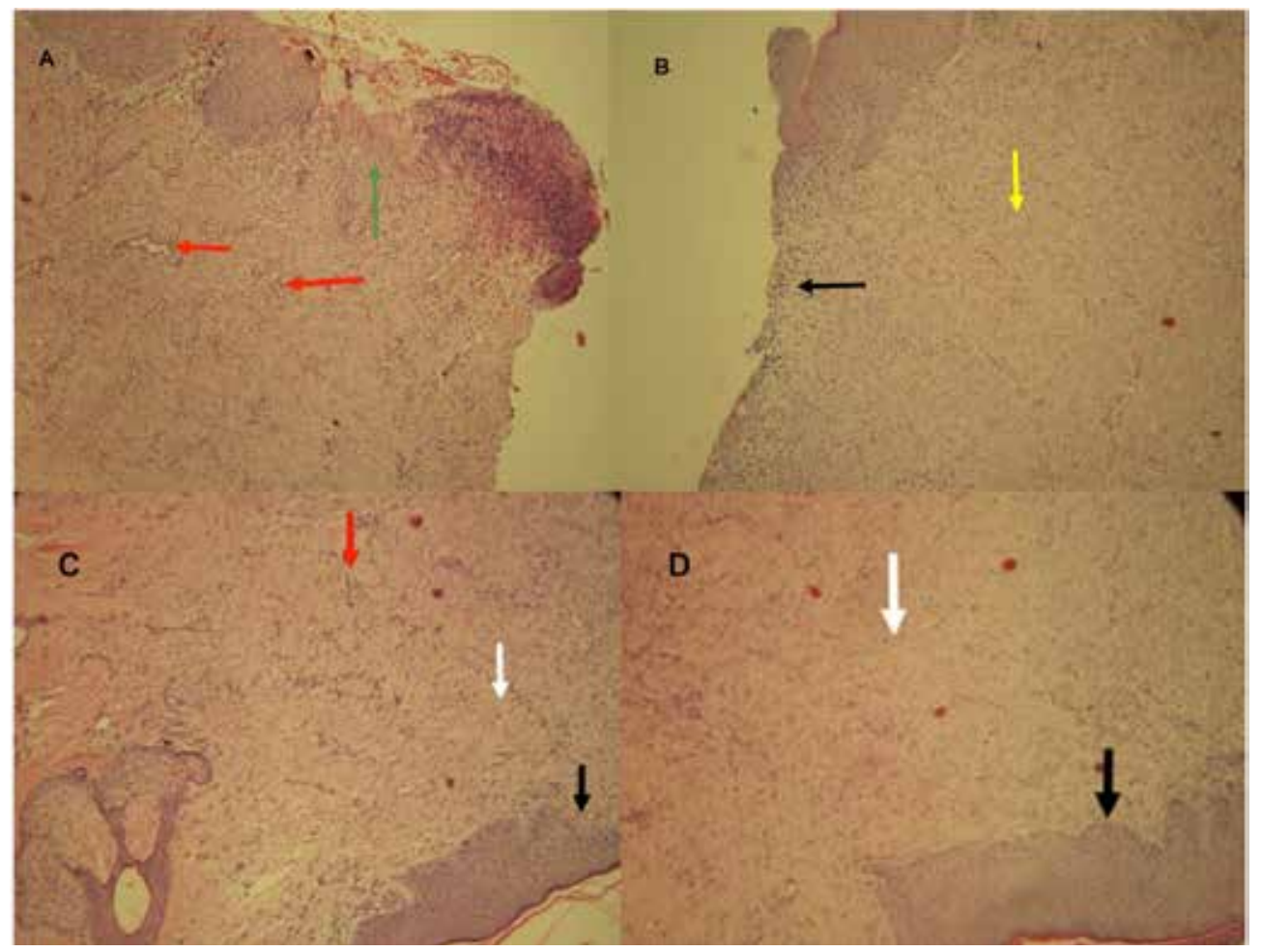

Figure 2 - Histopathological observations of lumbar wounds experimentally induced in horses. On image A, control group (GC), it is possible to observe incomplete epithelialization (green arrow), mild to moderate fibroblast proliferation, moderate collagen deposition, and mild to moderate vascular proliferation (red arrow). On image B, wounds treated with ozonized saline (GO), it is possible to observe incomplete epithelialization (black arrow), discrete to moderate fibroblast proliferation, and moderate to severe collagen deposition (yellow arrow). On image C, wounds treated with pure andiroba oil (GAP), it is possible to see complete epithelialization (black arrow), moderate fibroblast proliferation (white arrow), and discrete vascular proliferation (red arrow). On image $\mathrm{D}$, wounds treated with ozonized andiroba oil (GAO), it is possible to see complete epithelialization (black arrow) and fibroblast proliferation (white arrow). Photograph taken from the wound margins (100x), HE staining

On the $14^{\text {th }}$ day of evaluation, it was possible to observe that GAO wounds had moderate fibroblast proliferation, accentuated collagen deposition, and moderate vascular proliferation, still with presence of discrete PMN and $\mathrm{MN}$ infiltrate and areas of epithelialization in the wounds. On GAP and GO groups, these findings were observed.
However, areas of epithelialization were not seen. GC presented conditions inferior to those found in the other groups.

Histopathologic evaluation on day 21 revealed that wounds from GAO had an advanced epithelialization, accentuated fibroblast proliferation and collagen deposition, 
moderate vascular proliferation, and presence of PMN infiltrate and discrete viewing of MN. On GAP group, it was possible to observe advanced epithelialization, but a moderate fibroblast proliferation, accentuated collagen deposition, and moderate vascular proliferation with discrete PMN and MN infiltration. GO showed a moderate epithelialization and fibroblast proliferation, however inferior to GAO and GAP treatments, with accentuated collagen deposition and moderate vascular proliferation presenting discrete PMN and MN infiltrate. GC showed satisfactory progress in healing, but with an inferior evolution than the other treatments, showing moderate epithelialization, moderate fibroblast proliferation and collagen deposition, and severe vascular proliferation, with moderate PMN and MN infiltrate

\section{Discussion}

The choice of the size of the wounds was based on studies performed similarly in horses (MARTINS et al., 2003; SOUZA et al., 2006; OLIVEIRA JÚNIOR et al., 2012), as well as depth of the lesions (MAGALHÃES et al., 2008; OLIVEIRA JÚNIOR et al., 2012) including skin and subcutaneous tissue, without involving adjacent muscles. Initial total area of the wounds was similar to those of the authors mentioned above, but differed in format to Oliveira Júnior et al. (2012), who solely conducted square wounds in similar experiment. This standardization is essential for comparative studies of different therapies in the healing process of cutaneous wounds in horses. To avoid interference from the biopsies in the area of the wound, one side of the animal was destined to macroscopic evaluation and the other side for collection of biopsies (MARTINS et al., 2003; SOUZA et al., 2006; OLIVEIRA JÚNIOR et al., 2012).

Administration of nonsteroidal anti-inflammatory (NSAIDs), phenylbutazone, was performed in order to minimize the painful reaction related to the surgical procedure (GOMEZ et al., 2004; OLIVEIRA JÚNIOR et al., 2012; MARTINS et al., 2013). In the same line of thought, Martins et al. (2003) made use of buprenorphine. Although a possible delay in the healing process of secondary intention was described when administering phenylbutazone for five days (HUSSNI et al., 2010), no influence on the healing process was observed, as also described by other authors (GOMEZ et al., 2004; MARTINS et al., 2013). In the present study, even with administration of NSAID, there was local pain reaction more evident in GO and GC wounds on the $3^{\text {rd }}$ day of treatment. This may be explained by andiroba oil's analgesic effects due to blockage of inflammatory mediators (eicosanoids) (PENIDO et al., 2005). Although proposed protocol for the evaluation of local pain through behavioral analysis is considered subjective, blinded examination prevented that recorded results be influenced.

Complete healing time of the wounds was slightly inferior to the 35 days described for those treated with Triticum vulgare (SOUZA et al., 2006). Furthermore, it was superior to the 21 days described for wounds treated with comfrey and barbatimao, the 26 days described for those treated with calendula (MARTINS et al., 2003), and the 21 days for those treated with sunflower-seed oil (OLIVEIRA JÚNIOR et al., 2012).

Similarly, a delay in wound healing with the use of andiroba oil had already been described (BRITO et al., 2001). Anti-inflammatory action of andiroba oil is assigned to limonoids, tetranortriterpenoids that promote inhibition of the cellular influx and edema formation in mice (PENIDO et al., 2005). This cell influx inhabitation, which is already slow in horses (WILMINK; VAN WEEREN, 2004), is possibly responsible for the observed delay in the healing process. Despite this, histopathologic examination performed on the $3^{\text {rd }}$ day of evaluation did not suggest differences between the studied groups, with similar presence of PMN infiltration in GO, GAO, and GAP, contradicting the delay in healing time.

Contraction degree of the wounds analyzed in this study was inferior to the results described in the study by Oliveira Júnior et al. (2012), which used sunflower-seed oil. According to these authors, a contraction degree of $90.78 \%$ was observed. This might have been due to the presence of linoleic acid, known precursor of arachidonic acid, on the composition of sunflower-seed oil.

Regarding the influence of ozone on the degree of contraction, there was no difference between the treated groups. This fact differs from studies in guinea pigs, in which a greater and significant wound contraction was observed with consequent reduction of the residual area of the wounds in the group treated with ozonized oil, when compared to the control group and the group treated with pure oil (VALACCHI et al., 2010). Ozone increases the expression of pro inflammatory cytokines, such as interleukin 1 and tumor necrosis factors and adaptive responses, including activation of cyclooxygenase 2 in keratinocytes (VALACCHI et al., 2004). Following this line of thought, it was expected that a greater contraction 
degree be seen in the GO wounds of the present study, but such was not observed. It is noteworthy that in this group ozone was mixed with $\mathrm{NaCl} 0.9 \%$ solution and it is well known that ozone maintains its active stage for a longer period of time when mixed with oils (KIM et al., 2009), being unstable in aqueous solutions. Additionally, different ozone concentration can influence results and optimal concentrations have to be established, because like any other chemical substance, insufficient doses may not produce satisfactory results and excessive doses may be harmful.

In the macroscopic evaluation, none of the treatments used in this experiment led to local irritation in the wound area, different from studies where authors used aloe vera extract and nitrofurazone (RIBAS et al., 2005). Crust formation and serofibrinous exudate were not observed in any of the wounds in the present study, similarly to what was observed when using barbatimao (MARTINS et al., 2003). Presence of hyperemia in all wounds evaluated three days after induction, even with the use of systemic anti-inflammatory, was also described in an experiment studying the use of ketanserin in the healing process of induced wounds in horses (RIBEIRO et al., 2009). According to the referred author, the presence of redness,

\section{References}

BRITO, N. M. B.; SILVA, P. R. F.; SILVA, G. C. F.; CASELLA, S. F. M.; SAMPAIO, A. R. S.; CARVALHO, R. A. Macroscopic evaluation of the cicatrization of treated open cutaneous wounds with oil andiroba in rats. Revista Paraense de Medicina, v. 15, n. 2, p. 17-22, 2001.

CAVALCANTI NETO, A. T.; ARRUDA, T. E. P.; ARRUDA, T. T. P.; PEREIRA, S. L. S.; TURATTI, E. Comparative evaluation between copaiba oil-resin and chlorhexidine digluconate on wound healing. Revista de Odontologia da UNESP, v. 34, n. 2, p. 107-112, 2005.

COELHO, C. S.; GAMA, J. A. N.; OLIVEIRA JÚNIOR, L. A. T.; SILVA, B. S. F.; SOUZA, V. R. C.; ENDRINGER, D. C.; LENZ, D. Use of extracts of sunflower-seed oil (Helianthus annus L.) for the treatment of cutaneous injuries in equine metatarsus: a case report. Revista Brasileira de Plantas Medicinais, v. 14, n. 1, p. 125-129, 2012. doi: 10.1590/S1516-05722012000100018. discharge, swelling around the wound, and soreness are common

Increase in area of all experimental wounds during the first week of treatment has also been observed in other researches (BRITO et al., 2001; MARTINS et al., 2003). This increase is probably due to PMN influx to the wound and high production of various factors (IL-1, chemo attractants, reactive oxygen species) (WILMINK; VAN WEEREN, 2004), essential for the inflammatory response, and this response in horses is slower, as discussed previously.

Histopathological analysis reinforces macroscopic findings, with GAO showing more advantages on the healing process than the other options, such as the presence of fibroblast proliferation, collagen deposition, and neovascularization in the $14^{\text {th }}$ day of evaluation, leading to epithelialization in some areas of the wound (STASHAK, 1994).

\section{Conclusion}

It was possible to conclude that no significant differences were observed between treatments and all of them had benefits when comparing to control group. Therefore, both pure and ozonized andiroba oil can be good options for wound treatment in horses.

FARIAS, M. P. O.; SOUSA, D. P.; ARRUDA, A. C.; ARRUDA, M. S. P.; WANDERLEY, A. G.; ALVES, L. C.; FAUSTINO, M. A. G. In vitro effectiveness of the oil of the Carapa guianensis Aubl. (andiroba) in the control of Boophilus microplus (Acari: Ixodidae). Revista Brasileira de Plantas Medicinais, v. 9, n. 4, p. 68-71, 2007.

FREIRE, D. C. B.; BRITO-FILHA, C. R. C.; CARVALHOZILSE, G. A. Efeito dos óleos vegetais de andiroba (Carapa sp.) e Copaíba (Copaifera sp.) sobre forídeo, pragas de colméias, (Diptera: Phoridae) na Amazônia Central. Acta Amazonica, v. 36, n. 3, p. 365-368, 2006. doi: 10.1590/ S0044-59672006000300012.

GARROS, I. C.; CAMPOS, A. C. L.; TÂMARA, E. M.; TENÓRIO, S. B.; TORRES, O. J. M.; AGULHAM, M. A., ARAÚJO, A.C. F.;SANTIS-ISOLAN, M. B.; OLIVEIRA, R. M.; ARRUDA, E. C. M. Extrato de Passiflora edulis na cicatrização de feridas cutâneas abertas em ratos: estudo morfológico e 
histológico. Acta Cirúrgica Brasileira, v. 21, p. 55-65, 2006. Supplement 3. doi: 10.1590/S0102-86502006000900009.

GOMEZ, J. H.; SCHUMACHER, J.; LAUTEN, S. D.; SARTIN, E. A.; HATHCOCK, T. L.; SWAIM, S. F. Effects of 3 biological dressings on healing of cutaneous wounds on the limbs of horses. Canandian Journal of Veterinary Research, v. 68, n. 1, p. 49-55, 2004.

HUSSNI, C. A.; GROH, T. M.; ALVES, A. L. G.; CROCCI, A. J.; NICOLETTI, J. L. M.; WATANABE, M. J. Phenylbutazone effects on experimental wound healing in horses. Brazilian Journal of Veterinary Research and Animal Science, v. 47, n. 4, p. 262-267, 2010. doi: 10.11606/ issn.1678-4456.bjvras.2010.26824.

KIM, H. S.; NOH, S. U.; HAN, Y. W.; KIM, K. M.; KANG, H.; KIM, H. O.; PARK, Y. M. Therapeutic effects of topical application of ozone on acute cutaneous wound healing. Journal of Korean Medical Science, v. 24, n. 3, p. 368-374, 2009. doi: $10.3346 / j k m s .2009 .24 .3 .368$.

LEITE, A. P.; OLIVEIRA, B. G. R. B.; SOARES, M. F.; BARROCAS, D. L. R. Uso e efetividade da papaína no processo de cicatrização de feridas: uma revisão sistemática. Revista Gaúcha de Enfermagem, v. 33, n. 3, p. 198-207, Sep. 2012. doi: 10.1590/S1983-14472012000300026.

LIMA, D. C. M.; TANAKA, N. M.; GONÇALVES, R. C.; SILVA, L. C.; CUNHA FILHO, L. F. C. Granulated sugar on the healing of contaminated wound in sheep. UNOPAR Científica Ciências Biológicas e da Saúde, v. 14, n. 2, p. 111-114, 2012.

MAGALHÃES, M. S.; FECHINE, F. V.; MACEDO, R. N.; MONTEIRO, D. L.; OLIVEIRA, C. C.; BRITO, G. A.; MORAES, M. E.; MORAES, M. O. Effect of a combination of medium chain triglycerides, linoleic acid, soy lecithin and vitamins $\mathrm{A}$ and $\mathrm{E}$ on wound healing in rats. Acta Cirúrgica Brasileira, v. 23, n. 3, p. 262-269, 2008. doi: 10.1590/S0102-86502008000300009.

MARQUES, S. R.; PEIXOTO, C. A.; MESSIAS, J. B.; ALBUQUERQUE, A. R.; SILVA JÚNIOR, V. A. The effects of topical application of sunflower-seed oil on open wound healing in lambs. Acta Cirúrgica Brasileira, v. 19, n. 3, p. 196-209, 2004. doi: 10.1590/S0102-86502004000300005.
MARTINS, E. A. N.; INVERNIZZI, M. S.; CAMPOS, M. G. N.; TEODORO, P. A.; CONTIERI, M. B.; SILVA, L. C. L. C. Chitosan film in horses with experimentally induced skin wound. Ciência Rural, v. 43, n. 10, p. 1824-1830, 2013. doi: 10.1590/S0103-84782013001000015.

MARTINS, P. S.; ALVES, A. L. G.; HUSSNI, C. A.; SEQUEIRA, J. L.; NICOLETTI, J. L. M.; Thomassian, A. Comparação entre fitoterápicos de uso tópico na cicatrização de pele em equinos. Archives of Veterinary Science, v. 8, n. 2, p. 1-7, 2003. doi: 10.5380/avs.v8i2.4026.

OlIVEIRA JÚNIOR, L. A. T.; SOUZA, V. R. C.; ENDRINGER, D. C.; HENDRICKSON, D. A.; COELHO, C. S. Effects of topical application of sunflower-seed oil on experimentally induced wounds in horses. Journal Equine Veterinary Science, v. 32, n. 3, p. 139-145, 2012. doi: 10.1016/j.jevs.2011.08.006.

PENIDO, C.; CONTE, F. P.; CHAGAS, M. S.; RODRIGUES, C. A.; PEREIRA, J. F.; Henriques, M. G. Antiinflammatory effects of natural tetranortriterpenoids isolated from Carapa guianensis Aublet on zymosaninduced arthritis in mice. Inflammation Research, v. 55, n. 11, p. 457-464, 2006. doi: 10.1007/s00011-006-5161-8.

PENIDO, C.; COSTA, K. A.; PENNAFORTE, R. J.; COSTA, M. F.; PEREIRA, J. F.; SIANI, A. C.; HENRIQUES, M. G. Anti-allergic effects of natural tetranortriterpenoids isolated from Carapa guianensis Aublet on allergen-induced vascular permeability and hyperalgesia. Inflammation Research, v. 54, n. 7, p. 295-303, 2005.

PENNAFORTE, R.J.Estudodaatividadeantiinflamatória de duas espécies de plantas amazônicas. 2003. $70 \mathrm{f}$. Dissertação (Mestrado) - Instituto Oswaldo Cruz, Rio de Janeiro, 2003.

RIBAS, L. M.; NOGUEIRA, C. E. W.; BEIRA, F. T. A.; ALBURQUEQUE, L. P. A. N.; KICKHOFEL, E. Efeito cicatrizante do extrato aquoso de Triticum vulgare em feridas do tecido cutâneo de equinos. A Hora Veterinária, v. 25, n. 147, p. 27-29, 2005.

RIBEIRO, G.; MARTINS, C. B.; SILVA, M. A. G.; BORGES V. P.; LACERDA NETO, J. C. Uso tópico de ketanserina na cicatrização de feridas cutâneas induzidas 
em equinos. Arquivo Brasileiro de Medicina Veterinária e Zootecnia, v. 61, n. 1, p. 144-148, 2009. doi: 10.1590/ S0102-09352009000100020.

SOUZA, D. W.; MACHADO, T. S. L.; ZOPPA, A. L. V.; CRUZ, R. S. F.; GÁRAGUE, A. P. E.; SILVA, L. C. L. C. Experimental study of topical use of Triticum vulgare cream in induced skin wounds in horses. Revista Brasileira de Plantas Medicinais, v. 8, n. 3, p. 9-13, 2006.

STASHAK, T. S. Principles of wound healing. In: STASHAK, T. S. Equine wound management. London: Lea \& Febiger, 1994. p. 1-18.

TEIXEIRA, R. K. C.; HOUAT, A. P.; COSTA, F. L. S.; SARAIVA FILHO, J. C. P.; Yasojima, E. Y.; Brito, M. V. H. Effect of andiroba oil on survival of mice subjected to abdominal sepsis. Revista da Sociedade Brasileira de Clínica Médica, v. 10, n. 5, p. 407-409, 2012.

VALACCHI, G.; LIM, Y.; BELMONTE, G.; MIRACCO, C.; ZANARDI, I.; BOCCI, V.; TRAVAGLI, V. Ozonated sesame oil enhances cutaneous wound healing in SKH 1 mice. Wound Repair and Regeneration, v. 19, n. 1, p. 107115, 2010. doi: 10.1111/j.1524-475X.2010.00649.x.
VALACCHI, G.; PAGNIN, E.; CORBACHO, A. M.; OLANO, E.; DAVIS, P. A.; PACKER, L.; CROSS, C. E. In vivo ozone exposure induces antioxidant/stress-related responses in murine lung and skin. Free Radical Biology \& Medicine, v. 36, n. 5, p. 673-681, 2004. doi: 10.1016/j. freeradbiomed.2003.12.005.

VIANA, L. F. S.; WENCESLAU, A. A.; COSTA, S. C. L.; FIGUEIREDO, M. A. F.; ANDRADE, F. S. S. D.; FERREIRA, M. L. Tratamentos complementares para ferida com tecido de granulação exuberante em um equino: relato de caso. Revista Brasileira de Medicina Veterinária, v. 36, n. 4, p. 417-420, 2014.

WENDT, S. B. T. Comparação da eficácia da calêndula e do óleo de girassol na cicatrização por segunda intenção de feridas em pequenos animais. 2005. 85 f. Dissertação (Mestrado em Ciências Veterinárias) - Universidade Federal do Paraná, Curitiba, 2005.

Wilmink, J. M.; Van Weeren, P. R. Differences in wound healing between horses and ponies: application of research results to the clinical approach of equine wounds. Clinical Techniques in Equine Practice, v. 3, n. 2, p. 123-133, 2004. doi: 10.1053/j.ctep.2004.08.011. 